\title{
Emerging Functions of Natural IgM and Its Fc Receptor FCMR in Immune Homeostasis
}

\author{
Hongsheng Wang ${ }^{1 *}$, John E. Coligan ${ }^{2}$ and Herbert C. Morse III ${ }^{\text {* }}$ \\ ${ }^{1}$ Virology and Cellular Immunology Section, Laboratory of Immunogenetics, National Institute of Allergy and Infectious \\ Diseases, National Institutes of Health, Rockville, MD, USA, ${ }^{2}$ Receptor Cell Biology Section, Laboratory of Immunogenetics, \\ National Institute of Allergy and Infectious Diseases, National Institutes of Health, Rockville, MD, USA
}

\section{OPEN ACCESS}

Edited by:

Ana María Hernández, Center of Molecular Immunology,

Cuba

Reviewed by: Laurence Morel, University of Florida, USA Yoelys Cruz Leal, University of Havana, Cuba

*Correspondence: Hongsheng Wang wanghongs@niaid.nih.gov;

Herbert C. Morse III hmorse@niaid.nih.gov

Specialty section: This article was submitted to B Cell Biology, a section of the journal Frontiers in Immunology

Received: 08 January 2016 Accepted: 29 February 2016 Published: 15 March 2016

Citation:

Wang H, Coligan JE and Morse HC III (2016) Emerging Functions of Natural IgM and Its Fc Receptor FCMR in Immune Homeostasis. Front. Immunol. 7:99. doi: 10.3389/fimmu.2016.00099
Most natural lgM antibodies are encoded by germline lg sequences and are produced in large quantities by both mice and humans in the absence of intentional immunization. Natural lgM are reactive with many conserved epitopes, including those shared by microorganisms and autoantigens. As a result, these antibodies play important roles in clearing intruding pathogens, as well as apoptotic/necrotic cells and otherwise damaged tissues. While natural IgM binds to target structures with low affinity due to a lack of significant selection by somatic hypermutation, its pentameric structure with 10 antigen-binding sites enables these antibodies to bind multivalent target antigens with high avidity. Opsonization of antigen complexed with lgM is mediated by cell surface Fc receptors. While the existence of Fc alpha/mu receptor has been known for some time, only recently has the Fc receptor specific for IgM (FCMR) been identified. In this review, we focus on our current understandings of how natural IgM and FCMR regulate the immune system and maintain homeostasis under physiological and pathological conditions.

Keywords: natural IgM, FCMR, autoimmunity, homeostasis, inflammation

\section{INTRODUCTION}

Studies of IgG antibodies produced in response to foreign antigens have provided a wealth of information about the mechanisms involved in generating a seemingly limitless array of antigen-binding specificities by diversification of their antigen-binding domains through somatic recombination and mutation. In addition, a large number of investigations have shown that the effector functions of these antibodies are mediated through the interactions of their Fc domains with a series of isotyperestricted receptors expressed on a variety of hematopoietic cell types.

An Fc receptor specific for IgM, now termed FCMR (1), was defined only 8 years ago. Importantly, and in contrast to most secreted IgG antibodies, secreted IgM (sIgM) can be subdivided into natural and immune IgM. Natural IgM is found at equivalent levels in sera of normal and germ-free mice, and it is thought that exposure to natural antigens is responsible for its production. In addition, natural IgM is often polyreactive, whereas immune IgM is selected for antigen-specificity and is usually produced following exposure to pathogens. Because it is impossible to separate the effects of natural IgM from immune IgM when we evaluate the consequences of interactions between FCMR and an IgM molecule in non-immunized individuals; in this review, serum sIgM is taken to be synonymous to natural IgM. 
Over the last several years, advances in understanding the various functions of sIgM and its interactions with FCMR have been accelerated by the generation of knockout mice that lack sIgM or FCMR. The purpose of this review is to describe new aspects of the nature and functions of the sIgM-FCMR axis.

\section{NATURAL IgM, AN OVERVIEW}

sIgM exists in all vertebrate species including fishes, amphibians, reptiles, birds, and mammals (2). Both mice and humans have large quantities of circulating sIgM $(300-800 \mu \mathrm{g} / \mathrm{ml}$ for mice and $400-2300 \mu \mathrm{g} / \mathrm{ml}$ for humans). The serum levels of sIgM are maintained similarly in mice that are raised in pathogen-free, germ-free, or chemically defined antigen-free environments indicating that endogenous stimuli are responsible for its production $(3,4)$. The cellular origin of $\operatorname{sgM}$ has been postulated to be predominantly B-1 cells found in the peritoneal cavity (5). However, this view has recently been revised by evidence that B- 1 cells residing in the spleen and bone marrow are significant producers of sIgM (6). Other cell types including marginal zone $\mathrm{B}$ cells have also been implicated in the production of natural IgM (7). B-1 cells, particularly the $\mathrm{CD}^{+} \mathrm{B}-1 \mathrm{a}$ subset, belong to a stable population maintained by self-renewal independent of gut microbiomes $(8,9)$. B-1a cells, especially the $\mathrm{PC} 1^{\text {lo }}$ subset $(10)$, constantly migrate out of the peritoneum with some migrating to the spleen where they undergo activation and secret sIgM. In addition, the bone marrow is found to host a small number of $\mathrm{CD}^{-}$plasma cells originating from the peritoneum that likely contribute to long-term sIgM production (11). A thorough discussion of natural antibody-producing cells can be found in a recent elegant review (12).

Polyreactivity and autoreactivity are two prominent features found within the sIgM population. Prior studies with monoclonal natural antibodies including IgM and IgG isotypes demonstrated that a single natural IgM or IgG is capable of binding more than three apparently structurally unrelated antigens (13-15). Based on immunoadsorption experiments or immunoblotting using a panel of self-antigens, it has been estimated that $5-100 \%$ of normal mouse or human sera is autoreactive [Reviewed in Ref. (16)]. These properties of sIgM have been attributed to the germline configuration of their $\mathrm{V}$ region structures, characterized by enrichment of positively charged amino acids, especially arginine $(17,18)$. Also, compared to induced IgM antibodies, the $\mathrm{V}$ regions of sIgM have relatively higher frequencies of tyrosine and serine residues, which bear side-chain hydroxyl groups, allowing sIgM to bind various epitopes via ionic and hydrogen bonding (17, 18). These interactions, however, are usually of low affinity (19). Nevertheless, the polymeric binding between pentameric sIgM and a target antigen reaches a functional affinity (avidity) much higher than the intrinsic affinity $(20,21)$. By using the surface plasmon resonance technique to determine binding avidities, Diaw et al. analyzed five monoclonal sIgM against dissimilar autoantigens including cytoskeletal antigens and DNA. The kinetic binding constants of all five sIgM were indistinguishable from those observed for immune antibodies (22).

The biological functions of sIgM have been described to include removal of apoptotic cells, protection from infection, and tissue homeostasis $(16,23)$. The third function is attributed to sIgM-mediated clearance of tissue-breakdown molecules and binding to cell surface molecules on $\mathrm{B}$ and $\mathrm{T}$ cells to inhibit cell division and/or activation, thereby minimizing inflammation (16). This immunomodulatory role of sIgM has been confirmed by studies with two independently genetically engineered mouse strains lacking serum $\operatorname{IgM}\left(\mathrm{S}^{-/-}\right)(24,25)$. These mice exhibit abnormal B cell development, impaired antibody responses, and enhanced production of autoantibodies (see below).

\section{THE IgM Fc RECEPTOR, FCMR}

Originally identified and termed as TOSO [encoded by Fas apoptosis inhibitory molecule 3 (FAIM3)] in 1998 (26), FCMR was recently rediscovered and characterized as an IgM-specific Fc receptor $(27,28)$. A consensus nomenclature for this molecule has recently been proposed as FCMR (1). FCMR is a transmembrane protein with a predicted molecular weight of $\sim 41 \mathrm{KDa}$, but with heavily O-linked glycosylation in the extracellular domain, a mature molecule can reach $\sim 60 \mathrm{KDa}(26,27,29)$. The extracellular domain contains a single Ig-like domain with binding activity to the IgM Fc region, while the intracellular domain contains tyrosine residues that serve as phosphorylation sites to initiate/ mediate signaling cascades. A thorough review of the molecular features of FCMR has recently been published (30).

To date, most of our understanding of the functions of FCMR comes from studies of FCMR-deficient mice. Natural mutations of FCMR in humans have not been reported. There are three independently generated $\mathrm{Fcm} r$ gene knockout strains have been reported (31-34) and two of them were characterized in detail $(31,32,34)$ (Table 1). Clear differences exist among these mice, possibly due to the nature of gene targeting strategies, differing involvement of $129 / \mathrm{Sv}$ ES cells, extent of backcrossing to the B6 background, and husbandry environment. Readers are reminded of a recent report that revealed an astonishing "side effect" of passenger mutations of the 129 line that persists even after extensive backcrossing (35). This finding could explain why distinct knockout strains for the same gene often yield discrepant functional results.

\section{EXPRESSION OF FCMR}

The expression of FCMR in different cell types has been investigated at both the mRNA and protein levels by a number of investigators without complete agreement. The ImmGen database, a microarray-based public resource of mouse transcript expression (www.immgen.org), indicates a broad expression pattern of Fcmr among all lymphoid and myeloid cells tested, with relative expression levels ranging from $\sim 50$ in T cells, NK, DCs, myeloid, and stromal cells to $\sim 5000$ in B cells. Our quantitative PCR analyses of sorted populations revealed a similar pattern of expression, also with B cells expressing the highest levels (31). Northern blot analysis of human tissues also revealed a broad expression pattern of FCMR in lymphoid and non-lymphoid tissues $(26,28)$.

Fc receptor specific for IgM protein expression has been assessed in a variety of cell types using several monoclonal antibodies. Kubagawa and colleagues reported that FCMR 
TABLE 1 | Phenotypes of $\mathrm{Fcmr}^{-1-}$ mice.

\begin{tabular}{|c|c|c|c|c|c|}
\hline \multicolumn{2}{|c|}{ Reports by } & Choi et al. (31) & Ouchida et al. (34) & Honjo et al. (32) & Nguyen et al. (33) \\
\hline \multicolumn{2}{|l|}{ Strain } & Fcmrtmimak & \multicolumn{2}{|c|}{ Fcmrtm1Ohno } & $\mathrm{Fcmr}^{\mathrm{tm} 1.2 \mathrm{Khl}}$ \\
\hline \multicolumn{2}{|c|}{ Genetic manipulation } & $\begin{array}{l}\text { Deleted exons } 2-8 \text {. Involving 129/Sv } \\
\text { ES cells and backcrossing with C57BL/6 } \\
\text { mice. The Neo gene cassette was not } \\
\text { deleted after recombination }\end{array}$ & \multicolumn{2}{|c|}{$\begin{array}{l}\text { Deleted exons } 2-4 \text {. Involving } 129 / \mathrm{Sv} \text { ES cells and backcrossing } \\
\text { with C57BL/6 mice. The Neo gene cassette was deleted after } \\
\text { recombination }\end{array}$} & $\begin{array}{l}\text { Deleted exons } 4-7 . \text { The Neo } \\
\text { gene cassette was deleted } \\
\text { after recombination. Pure } \\
\text { B6 background }\end{array}$ \\
\hline \multirow[t]{3}{*}{ B cells } & $\mathrm{BM}$ & $\begin{array}{l}\text { Small pre-B } \downarrow \\
\text { Immature } B \downarrow\end{array}$ & Not changed & Not changed & NR \\
\hline & Spleen & FOB $\downarrow$, MZB unchanged & $\begin{array}{l}\text { FOB unchanged, MZB } \downarrow \text {, } \\
\text { transitional } \mathrm{B} \uparrow\end{array}$ & $\mathrm{MZB} \downarrow, \mathrm{B}-1 \uparrow$ & B cells $\downarrow$ \\
\hline & PerC & $\mathrm{B}-1 \mathrm{a} \uparrow, \mathrm{B}-2 \downarrow$ & Not changed & Not changed & NR \\
\hline \multirow{2}{*}{\multicolumn{2}{|c|}{$\begin{array}{l}\text { T cells } \\
\text { Basal Ig levels }\end{array}$}} & Not changed & Not changed & Not changed & Not changed \\
\hline & & IgG1 $\downarrow$, No change for other classes & $\operatorname{lgM} \uparrow$, no change for total lgG & $\begin{array}{l}\lg \mathrm{M} \uparrow, \lg \mathrm{G} 3 \uparrow, \text { no change for } \\
\text { other classes }\end{array}$ & NR \\
\hline \multicolumn{2}{|c|}{ TI responses } & Enhanced & Reduced & $\begin{array}{l}\text { Phosphorylcholine-specific } \\
\text { responses are enhanced }\end{array}$ & NR \\
\hline \multicolumn{2}{|c|}{ TD responses } & Enhanced & Reduced & Reduced & NR \\
\hline \multicolumn{2}{|c|}{$\begin{array}{l}\text { Responses to infectious } \\
\text { pathogens }\end{array}$} & NR & NR & $\begin{array}{l}\text { IgM and IgG3 responses to } \\
\text { low doses of Streptococcus } \\
\text { pneumoniae are enhanced }\end{array}$ & NR \\
\hline \multicolumn{2}{|c|}{$\begin{array}{l}\text { Spontaneous autoantibody } \\
\text { production }\end{array}$} & Anti-ds-DNA and ANAs $\uparrow$ & $\begin{array}{l}\text { Anti-DNA, -rheumatoid } \\
\text { factor, and ANAs } \uparrow\end{array}$ & $\begin{array}{l}\text { Anti-DNA, -chromatin, and } \\
\text { ANAs } \uparrow\end{array}$ & NR \\
\hline
\end{tabular}

$N R$, not reported.

expression was restricted to human $\mathrm{B}, \mathrm{T}$, and NK cells, and mouse B cells $(27,32)$. The lack of expression of mouse FCMR by non-B cells was confirmed by Ohno and colleagues $(28,34)$. However, Lang et al. using a different monoclonal antibody reported expression of FCMR on myeloid cells (36). On the other hand, Honjo et al. could not detect expression of exon 2 mRNA of Fcmr and FCMR protein in granulocytes with their monoclonal antibodies (37). Analysis of FCMR expression is complicated by the fact that it undergoes internalization after binding IgM (29). Freshly isolated tonsillar B and T cells are negative for FCMR on the cell surface; however, these cells become positive for FCMR after a brief culture with IgMnegative medium in vitro (27). Therefore, detection of FCMR at the cell membrane becomes problematic and ambiguous depending on the method used for study. In addition, future studies are warranted to determine whether the various antiFCMR monoclonal antibodies recognize the same or alternative forms of FCMR expressed in different tissues.

It should be recognized that FCMR, while specific for IgM, is not the only cell surface $\mathrm{Fc}$ receptor capable of binding IgM. The Fc $\alpha / \mu$ receptor (FCA/MR), encoded by the FCA/MR gene in humans, is an unusual Fc receptor in that it binds to two different antibody isotypes, IgA, and IgM (38). The receptor is broadly expressed in humans and mice, but with significant differences in expression patterns between the two species, particularly on hematopoietic cells (39). Both IgA and IgM cross-compete for binding to the mouse receptor suggesting a common site of interaction. Pentameric IgM does not have to contain J chain to bind the receptor (40).

A second receptor with dual specificity for $\operatorname{IgA}$ and $\operatorname{IgM}$ is the polymeric immunoglobulin receptor, PIGR. This receptor only binds polymeric IgA and IgM associated with the J chain at high affinities (41). In contrast to FCA/MR and FCMR, PIGR is expressed only on epithelial cells (42).

\section{SIGNALING POTENTIAL OF FCMR}

The intracellular domain of FCMR contains several tyrosine residues but lacks a commonly present immunoreceptor tyrosine-based activation motif (ITAM) and/or the immunoreceptor tyrosine-based inhibition motif (ITIM) (27). However, the FCMR cytoplasmic tail does contain an Asp- $\mathrm{X}_{5}-\mathrm{Asp}-$ Tyr $^{401}$-Ile-Asn sequence that matches the recently identified immunoglobulin tail tyrosine (ITT) phosphorylation motif Glu/Asp- $\mathrm{X}_{6-7}-$ Asp-Tyr-X-Asn present in membrane IgG (mIgG) and $\mathrm{mIgE}$ (43). This consensus motif is found to amplify BCR signals in class-switched memory B cells by recruiting the adaptor Grb2, thereby allowing switched memory B cells to respond more quickly and vigorously than primary $B$ cells to secondary exposures to antigens $(43,44)$. Therefore, the ITT motif of FCMR could serve as a molecular platform to interact with and influence the BCR signaling pathway. In fact, cross linking FCMR with either anti-FCMR monoclonal antibodies or preformed IgM immune complexes induced phosphorylation of tyrosine and serine residues of FCMR in B cells (27) and phosphorylation of PLC- $\gamma$ and Erk1/2 in NK cells (45). Our analyses also showed that FCMR positively modulates tonic BCR signaling. The basal levels of phospho-Syk in pre-B, MZ, and B-1a cells were lower in $\mathrm{Fcmr}^{-1-}$ mice than WT controls (31). Ligation of FCMR alone did not affect cellular proliferation and survival (34). However, BCR-induced proliferation and survival were reduced in the absence of $\operatorname{FCMR}(31,34)$. 
Moreover, ligation of FCMR had no effect on LPS or anti-CD40 antibody-induced proliferation and survival $(31,34)$. These results argue that FCMR more closely approximates the activity of BCR than TLR or CD40 on the surface of B cells. Therefore, it is conceivable that FCMR plays a modulatory role in BCR signaling that supports survival.

\section{THE SIgM-FCMR AXIS IN REGULATION OF EARLY B CELL DEVELOPMENT}

Early stages of B cell development are characterized by ordered gene expression consisting of $\mathrm{H}$ and $\mathrm{L}$ chain gene rearrangements in pro- $\mathrm{B}$ and pre- $\mathrm{B}$ cells, respectively. The expression of productive $\mu \mathrm{H}$ chains leads to assembly and expression of pre-BCRs on the surface of pre-B cells. In conjunction with the IL-7 signaling, pre-BCRs trigger clonal expansion for approximately six divisions (46) and upregulate expression of IRF4, which promotes pre-B cell dissociation from stromal cells, a critical step leading to differentiation of small pre-B cells and L chain gene rearrangement (47).

The expression levels of FCMR in early B cells gradually increases starting from pro-B to pre-B and to immature B cells (ImmGen database), similar to our assessment by qPCR (31). In the absence of FCMR, as noted in the Fcmr ${ }^{\text {tmlMak }}$ strain but not the Fcmr ${ }^{\text {tm1Ohno }}$ strain (Table 1), the development of pre-B and immature B cells was significantly reduced (31). Remarkably, $\mathrm{S} \mu^{-/-}$mice lacking sIgM exhibited similar deficiencies in pre-B and immature B cells $(31,48)$. Therefore, the sIgM-FCMR axis may represent a positive feedback loop promoting development and maturation of early B cells. Indeed, irradiated normal recipient mice receiving WT hematopoietic stem cells (HSCs) and sIgM-containing sera generated significantly more pre-B cells than recipients of WT HSCs and sIgM-deficient sera (31). This observation suggests that sIgM could enhance generation of pre-B and immature B cells in a FCMR-dependent fashion (31).

\section{THE sIgM-FCMR AXIS IN REGULATION OF LATE STAGES OF B CELL DEVELOPMENT}

Fc receptor specific for IgM deficiency in mice was associated with altered distributions of peripheral B cells. The Fcmr ${ }^{\text {tmlMak }}$ strain exhibited reduced numbers of splenic follicular B cells, but the numbers of MZ B cells remained unchanged (31). In the peritoneum, the frequencies of $\mathrm{B}-1 \mathrm{a}$ cells were increased while B-2 cells in this strain were decreased (31). In contrast, the Fcmr ${ }^{\text {tmiohno }}$ strain exhibited reduced numbers of MZ B cells, increased transitional B cells and B-1 cells in the spleen, and no change in peritoneal B cells $(32,34)$ (Table 1). The differences in distribution of $\mathrm{B}$ cells between the two strains are also associated with differences between the strains in basal levels of serum immunoglobulins in naive mice (Table 1) $(31,32,34,48)$.

Our parallel assessments of $S \mu^{-/-}$and Fcmr ${ }^{\text {tmlMak }}$ mice revealed strikingly similar changes in peripheral B cells: reduced numbers of FO but increased numbers of MZ B cells in the spleen, and increased numbers of B-1a cells but reduced B-2 cells in the peritoneum (31). A second $\mathrm{S} \mu^{-/-}$strain also exhibited expansion of MZ and B-1a cells and reduction in FO B cells (25). These data agree with the conclusion that the sIgM-FCMR axis may promote FO B cell development. Regarding B-1 cells, Nguyen et al. recently reported that peritoneal $\mathrm{CD}^{+} \mathrm{B}$ cells in $\mathrm{S} \mu^{-/-}$mice were not "regular" B-1a cells but exhibited characteristics of "anergic" B cells (48). They further showed that the lack of sIgM in $\mathrm{S}^{-/-}$mice not only altered $\mathrm{B}$ cell numbers (reduced FO and expanded MZ B cells), confirming our analyses (31), but also fundamentally altered the $\mathrm{B}$ cell repertoire (the usage of $\mathrm{V}_{\mathrm{H}}$ genes) and selection (48). More importantly, administration of sIgM into $\mathrm{S} \mu^{-/-}$mice reversed the MZ/FO B cell ratio and mostly restored normal B cell development $(48,49)$. These results strongly suggest that the sIgM-FCMR axis does indeed modulate differentiation of peripheral B cells.

\section{THE sIgM-FCMR AXIS IN REGULATION OF T-INDEPENDENT IMMUNE RESPONSES}

Immunization of the Fcmr ${ }^{\text {tmlMak }}$ strain with NP-LPS stimulated increased levels of plasma cell development and secretion of IgM antibodies (31). This data can be explained by increased numbers of peritoneal B-1a cells in $\mathrm{Fcmr}^{-/-}$mice as B-1a cells are the primary responders to NP-LPS challenge in this setting (31). Immunization of Fcmr ${ }^{\text {tmlMak }}$ mice with NP-FICOLL, which predominantly activates MZ B cells, resulted in moderate increases in plasma cells without a significant increase in sIgM, which seems to correlate with relatively normal numbers of $\mathrm{MZ}$ $B$ cells in this strain (31). In contrast, studies of the Fcmr ${ }^{\text {tmlohno }}$ strain yielded opposing results, i.e., reduced production of sIgM and IgG following NP-FICOLL immunization (34) (Table 1). This discrepancy could be due to the fact that the MZ B cell compartment is reduced in the $\mathrm{Fcmr}^{\text {tmlohno }}$ strain but remains unchanged (if not slightly expanded) in the Fcmr ${ }^{\text {tmlMak }}$ strain. By using a complicated antigen, Streptococcus pneumoniae (R36A), Honjo et al. showed increased IgM and IgG3 responses to the carbohydrate phosphorylcholine (PC), epitope of the pathogen,

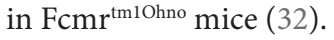

Previous studies in $\mathrm{S}^{-/-}$mice revealed enhanced production of IgG2a antibodies following immunization with NP-FICOLL (50). Similar findings were reported in another $\mathrm{S}^{-/-}$strain (25). Taken together, these results suggest that the sIgM-FCMR pathway may negatively regulate TI immune responses likely through modulating the sensitivity of responding B cells.

\section{THE sIgM-FCMR AXIS IN REGULATION OF T-DEPENDENT IMMUNE RESPONSES}

Studies of TD immune responses in Fcmrtmiohno and Fcmr ${ }^{\text {tm1Mak }}$ mice have also yielded conflicting results. Our analyses in the $\mathrm{Fcmr}^{\mathrm{tm} 1 \mathrm{Mak}}$ strain revealed a moderate increase in primary IgM but not of IgG2b responses following immunization with NP-KLH/alum (31). During a recall immune response, FCMRdeficient mice produced significantly more germinal centers and plasma cells but only exhibited subtle differences in overall serum 
antibody levels (31). In contrast, following a similar immunization protocol, Ouchida et al. and Honjo et al. reported that the Fcmr ${ }^{\text {tmlohno }}$ mice developed generally decreased TD immune responses $(32,34)$ (Table 1 ). Given the fact that the antibody responses elicited in both strains were relatively moderate, we believe that the role of FCMR in TD immune responses may be limited.

Previous studies of $S \mu^{-/-}$mice indicated that $\operatorname{sgM}$ is required to elicit optimal TD immune responses because in the absence of sIgM, $\mathrm{S} \mu^{-/-}$mice produced significantly lower levels of IgG1 anti-NP antibodies, and antibody affinity maturation was also delayed (25). However, injection of sIgM into $\mathrm{S} \mu^{-/-}$mice before immunization increased NP-specific IgG1 responses (25). These results suggest that sIgM could augment TD humoral responses, but whether this was mediated by sIgM-mediated antigen processing/presentation, or FCMR-mediated signaling that renders $\mathrm{B}$ cells hyperresponsive to activation signals, or both, remains to be determined.

\section{THE SIgM-FCMR AXIS SUPPRESSES DEVELOPMENT OF AUTOIMMUNITY}

Spontaneous production of increased levels of autoreactive antibodies, including anti-DNA and anti-nuclear antibodies, was detected in both FCMR-deficient strains (Table 1). Surprisingly, the existence of these autoantibodies in FCMR-deficient mice was insufficient to induce pathology, e.g., glomerular damage common to lupus-like diseases. Introducing Fcmr deficiency onto the autoimmune-prone B6.MRL Fas ${ }^{\mathrm{lpr} / \mathrm{pr}}$ background accelerated development of autoreactive antibodies but still had no effect on severity of renal pathology and function or overall survival (51). These results suggest that FCMR acts to inhibit activation of nonpathogenic autoreactive B cells.

Absence of sIgM in $\mathrm{S}^{-/-}$mice was also associated with accelerated development of IgG autoantibodies (48, 52, 53). Similar to FCMR-deficient mice, both $\mathrm{S} \mu^{-/-}$strains spontaneously generated IgG anti-DNA autoantibodies (52, 53). Immune complex deposition in the kidneys was observed in a small proportion of mice (53). When $S \mu^{-l-}$ mice were bred to $M R L^{\text {lpr/lpr }}$ mice, the progeny exhibited accelerated development of IgG autoantibodies and autoimmune disease (52). Moreover, adoptive transfer of $\mathrm{S} \mu^{-/-}$BM cells into recipient mice containing normal levels of sIgM abrogated anti-nuclear antibody development (48). Thus, sIgM and FCMR may negatively regulate autoimmunity through the sIgM-FCMR pathway not withstanding that sIgM may also modulate autoimmune responses through FCMR-independent mechanisms, such as complement fixation, immune complex uptake, and antigen presentation (23).

In addition to the functions of FCMR in the above lupus model, Lang et al. studied the roles of FCMR in an experimental autoimmune encephalomyelitis (EAE) model and demonstrated that $\mathrm{Fcmr}^{\text {tmlMak }}$ mice were resistant to EAE (54). While changes in expression of IL-17 in T cells were not observed in this report (54), a more recent study using single cell RNA-sequencing in isolated Th17 cells identified a strong correlation between expression of FCMR and the Th17 cytokine signature (55). Indeed,
FCMR-deficient T cells fail to produce IL-17A upon stimulation (55). IL-17A is a critical driving cytokine for EAE (56). Thus, FCMR may promote pathogenesis of Th17-mediated diseases.

\section{DOES FCMR PLAY A ROLE IN CONTROLLING INFECTION?}

While sIgM has long been postulated to play an important role as first line in defense against infectious agents (2), there are also indications that FCMR may play a role during inflammatory responses to infection. Honjo et al. immunized $\mathrm{Fcmr}^{\mathrm{tm} 1 \mathrm{Ohno}}$ mice with a live attenuated strain of $S$. pneumoniae (R36A) to examine antigen-specific immune responses against the bacterial PC and protein determinants (32). While the FCMR-deficient mice successfully elicited anti-PC antibody responses, they failed to generate anti-protein antibody responses (32). This result suggests that FCMR has discrete roles in B cells (possibly coupled with specificity of the BCR) in responding to protein and non-protein determinants of live pathogens.

Lang et al. performed wide range analyses of the Fcmr ${ }^{\text {tm1Mak }}$ strain infected with Listeria (36). FCMR-deficient mice were resistant to LPS-induced septic shock and failed to control Listeria infection. This phenotype is associated with decreased systemic production of IFN- $\gamma$, IL-12, and IL-6 in FCMRdeficient mice (36). While most of the changes in this model were attributed to absence of FCMR in phagocytes, including monocytes, macrophages, and granulocytes (36), the expression of FCMR by these myeloid cells was questioned by Honjo et al. who failed to detect expression of exon 2 of Fcmr by PCR and protein by FACS in granulocytes (37). More recently, Lang et al. have reported that FCMR is required for development and function of inflammatory dendritic cells (iDCs) (57). FCMR mutant mice were deficient for iDCs in the liver and thereby failed to recruit and activate $\mathrm{CD}^{+} \mathrm{T}$ cells to clear lymphocytic choriomeningitis virus (57). Because the expression levels of FCMR transcripts in granulocytes and DCs are about 100fold lower than in B cells (ImmGen database) and it remains unknown whether infection could upregulate expression of FCMR in granulocytes and DCs, future studies are warranted to determine the molecular mechanisms of FCMR action in non-B cells in response to infection.

\section{CONCLUDING REMARKS}

It is becoming broadly accepted that sIgM has protective functions in defense against infection and is important for maintaining tissue homeostasis. Earlier studies have revealed that sIgM binds to infectious agents, as well as altered self-antigens, and that sIgM-antigen complexes activate the complement cascade and initiate inflammatory responses. The recent identification of FCMR has provided new insights into the mechanisms of sIgM function in vivo. While evidence of the beneficial effects of sIgM on survival have dominated the literature, it is worth noting that sIgM can also play pathogenic roles under certain circumstances. For example, natural IgM is critical for development of inflammation and damage in a model of ischemia-reperfusion 
injury (58-61). In this case, sIgM binds to damaged tissue and activates the complement cascade causing massive inflammatory responses. Blocking sIgM binding to modified self-antigens with an anti-annexin IV single-chain antibody ( $\mathrm{scFv}$ ) significantly reduced graft inflammation and injury (58). Recently, Panzer et al. reported that injection of sIgM into B-cell-deficient $\mu \mathrm{MT}$ mice induced albuminuria in a complement-induced glomerular disease model (62). These observations raise a note of caution regarding postulated application of intravenous IgM (IVIgM) (63), a homolog of intravenous IgG (IVIg), to the treatment of autoimmune and inflammatory diseases. More recently, Brenner et al. reported that a FCMR-Fc fusion protein comprising the extracellular domain of FCMR exhibited therapeutic effects by inhibiting MOG-induced neuroinflammatory responses in an EAE model (54). An anti-FCMR monoclonal antibody has also

\section{REFERENCES}

1. Kubagawa H, Carroll MC, Jacob CO, Lang KS, Lee KH, Mak T, et al. Nomenclature of Toso, Fas apoptosis inhibitory molecule 3, and IgM FcR. J Immunol (2015) 194:4055-7. doi:10.4049/jimmunol.1500222

2. Boyden SV. Natural antibodies and the immune response. Adv Immunol (1966) 5:1-28. doi:10.1016/S0065-2776(08)60271-0

3. Coutinho A, Kazatchkine MD, Avrameas S. Natural autoantibodies. Curr Opin Immunol (1995) 7:812-8. doi:10.1016/0952-7915(95)80053-0

4. Pereira P, Forni L, Larsson EL, Cooper M, Heusser C, Coutinho A. Autonomous activation of B and T cells in antigen-free mice. Eur J Immunol (1986) 16:685-8. doi:10.1002/eji.1830160616

5. Baumgarth N, Herman OC, Jager GC, Brown L, Herzenberg LA. Innate and acquired humoral immunities to influenza virus are mediated by distinct arms of the immune system. Proc Natl Acad Sci U S A (1999) 96:2250-5. doi:10.1073/pnas.96.5.2250

6. Choi YS, Dieter JA, Rothaeusler K, Luo Z, Baumgarth N. B-1 cells in the bone marrow are a significant source of natural IgM. Eur J Immunol (2012) 42:120-9. doi:10.1002/eji.201141890

7. Ichikawa D, Asano M, Shinton SA, Brill-Dashoff J, Formica AM, Velcich A, et al. Natural anti-intestinal goblet cell autoantibody production from marginal zone B cells. J Immunol (2015) 194:606-14. doi:10.4049/jimmunol.1402383

8. Ha SA, Tsuji M, Suzuki K, Meek B, Yasuda N, Kaisho T, et al. Regulation of B1 cell migration by signals through Toll-like receptors. J Exp Med (2006) 203:2541-50. doi:10.1084/jem.20061041

9. Hardy RR. B-1 B cells: development, selection, natural autoantibody and leukemia. Curr Opin Immunol (2006) 18:547-55. doi:10.1016/j.coi.2006.07.010

10. Wang H, Shin DM, Abbasi S, Jain S, Kovalchuk AL, Beaty N, et al. Expression of plasma cell alloantigen 1 defines layered development of B-1a B-cell subsets with distinct innate-like functions. Proc Natl Acad Sci U S A (2012) 109:20077-82. doi:10.1073/pnas.1212428109

11. Reynolds AE, Kuraoka M, Kelsoe G. Natural IgM is produced by CD5-plasma cells that occupy a distinct survival niche in bone marrow. J Immunol (2015) 194:231-42. doi:10.4049/jimmunol.1401203

12. Savage HP, Baumgarth N. Characteristics of natural antibody-secreting cells. Ann N Y Acad Sci (2015) 1362:132-42. doi:10.1111/nyas.12799

13. Dighiero G, Lymberi P, Mazie JC, Rouyre S, Butler-Browne GS, Whalen RG, et al. Murine hybridomas secreting natural monoclonal antibodies reacting with self antigens. J Immunol (1983) 131:2267-72.

14. Prabhakar BS, Saegusa J, Onodera T, Notkins AL. Lymphocytes capable of making monoclonal autoantibodies that react with multiple organs are a common feature of the normal B cell repertoire. J Immunol (1984) 133:2815-7.

15. Seigneurin JM, Guilbert B, Bourgeat MJ, Avrameas S. Polyspecific natural antibodies and autoantibodies secreted by human lymphocytes immortalized with Epstein-Barr virus. Blood (1988) 71:581-5.

16. Avrameas S, Ternynck T. Natural autoantibodies: the other side of the immune system. Res Immunol (1995) 146:235-48. doi:10.1016/0923-2494(96)80259-8 been shown to be beneficial in experimental malaria infection (64). Future studies are warranted to determine whether blockade of FCMR could be a therapeutic approach to treat autoimmune and inflammatory diseases.

\section{AUTHOR CONTRIBUTIONS}

All authors listed, have made substantial, direct, and intellectual contribution to the work, and approved it for publication.

\section{ACKNOWLEDGMENTS}

This work was supported by the Intramural Research Programs of the NIH, National Institute of Allergy and Infectious Diseases (NIAID) (HW, JC, and HM).

17. Baccala R, Quang TV, Gilbert M, Ternynck T, Avrameas S. Two murine natural polyreactive autoantibodies are encoded by nonmutated germ-line genes. Proc Natl Acad Sci U S A (1989) 86:4624-8. doi:10.1073/pnas.86.12.4624

18. Conger JD, Sage HJ, Corley RB. Correlation of antibody multireactivity with variable region primary structure among murine anti-erythrocyte autoantibodies. Eur J Immunol (1992) 22:783-90. doi:10.1002/eji.1830220323

19. Nakamura M, Burastero SE, Ueki Y, Larrick JW, Notkins AL, Casali P. Probing the normal and autoimmune B cell repertoire with Epstein-Barr virus. Frequency of B cells producing monoreactive high affinity autoantibodies in patients with Hashimoto's disease and systemic lupus erythematosus. J Immunol (1988) 141:4165-72.

20. Adib-Conquy M, Avrameas S, Ternynck T. Monoclonal IgG and IgM autoantibodies obtained after polyclonal activation, show reactivities similar to those of polyclonal natural autoantibodies. Mol Immunol (1993) 30:119-27. doi:10.1016/0161-5890(93)90083-N

21. Ternynck T, Avrameas S. Murine natural monoclonal autoantibodies: a study of their polyspecificities and their affinities. Immunol Rev (1986) 94:99-112. doi:10.1111/j.1600-065X.1986.tb01166.x

22. Diaw L, Magnac C, Pritsch O, Buckle M, Alzari PM, Dighiero G. Structural and affinity studies of IgM polyreactive natural autoantibodies. JImmunol (1997) 158:968-76.

23. Gronwall C, Silverman GJ. Natural IgM: beneficial autoantibodies for the control of inflammatory and autoimmune disease. J Clin Immunol (2014) 34(Suppl 1):S12-21. doi:10.1007/s10875-014-0025-4

24. Boes M, Prodeus AP, Schmidt T, Carroll MC, Chen J. A critical role of natural immunoglobulin $\mathrm{M}$ in immediate defense against systemic bacterial infection. J Exp Med (1998) 188:2381-6. doi:10.1084/jem.188.12.2381

25. Ehrenstein MR, O'Keefe TL, Davies SL, Neuberger MS. Targeted gene disruption reveals a role for natural secretory $\operatorname{IgM}$ in the maturation of the primary immune response. Proc Natl Acad Sci U S A (1998) 95:10089-93. doi:10.1073/ pnas.95.17.10089

26. Hitoshi Y, Lorens J, Kitada SI, Fisher J, LaBarge M, Ring HZ, et al. Toso, a cell surface, specific regulator of Fas-induced apoptosis in T cells. Immunity (1998) 8:461-71. doi:10.1016/S1074-7613(00)80551-8

27. Kubagawa H, Oka S, Kubagawa Y, Torii I, Takayama E, Kang DW, et al. Identity of the elusive IgM Fc receptor (FcmuR) in humans. J Exp Med (2009) 206:2779-93. doi:10.1084/jem.20091107

28. Shima H, Takatsu H, Fukuda S, Ohmae M, Hase K, Kubagawa H, et al. Identification of TOSO/FAIM3 as an Fc receptor for IgM. Int Immunol (2010) 22:149-56. doi:10.1093/intimm/dxp121

29. Vire B, David A, Wiestner A. TOSO, the Fcmicro receptor, is highly expressed on chronic lymphocytic leukemia B cells, internalizes upon IgM binding, shuttles to the lysosome, and is downregulated in response to TLR activation. J Immunol (2011) 187:4040-50. doi:10.4049/jimmunol.1100532

30. Kubagawa H, Kubagawa Y, Jones D, Nasti TH, Walter MR, Honjo K. The old but new IgM Fc receptor (FcmuR). Curr Top Microbiol Immunol (2014) 382:3-28. doi:10.1007/978-3-319-07911-0_1 
31. Choi SC, Wang H, Tian L, Murakami Y, Shin DM, Borrego F, et al. Mouse IgM Fc receptor, FCMR, promotes B cell development and modulates antigen-driven immune responses. J Immunol (2013) 190:987-96. doi:10.4049/ jimmunol.1202227

32. Honjo K, Kubagawa Y, Jones DM, Dizon B, Zhu Z, Ohno H, et al. Altered Ig levels and antibody responses in mice deficient for the Fc receptor for IgM (FcmuR). Proc Natl Acad Sci U S A (2012) 109:15882-7. doi:10.1073/ pnas.1206567109

33. Nguyen XH, Lang PA, Lang KS, Adam D, Fattakhova G, Foger N, et al. Toso regulates the balance between apoptotic and nonapoptotic death receptor signaling by facilitating RIP1 ubiquitination. Blood (2011) 118:598-608. doi:10.1182/blood-2010-10-313643

34. Ouchida R, Mori H, Hase K, Takatsu H, Kurosaki T, Tokuhisa T, et al. Critical role of the IgM Fc receptor in IgM homeostasis, B-cell survival, and humoral immune responses. Proc Natl Acad Sci U S A (2012) 109:E2699-706. doi:10.1073/pnas.1210706109

35. Vanden Berghe T, Hulpiau P, Martens L, Vandenbroucke RE, Van Wonterghem E, Perry SW, et al. Passenger mutations confound interpretation of all genetically modified congenic mice. Immunity (2015) 43:200-9. doi:10.1016/j. immuni.2015.06.011

36. Lang KS, Lang PA, Meryk A, Pandyra AA, Boucher LM, Pozdeev VI, et al. Involvement of Toso in activation of monocytes, macrophages, and granulocytes. Proc Natl Acad Sci U S A (2013) 110:2593-8. doi:10.1073/ pnas. 1222264110

37. Honjo K, Kubagawa Y, Kubagawa H. Is Toso/IgM Fc receptor (FcmuR) expressed by innate immune cells? Proc Natl Acad Sci U S A (2013) 110:E2540-1. doi:10.1073/pnas.1304904110

38. Shibuya A, Sakamoto N, Shimizu Y, Shibuya K, Osawa M, Hiroyama T, et al. Fc alpha/mu receptor mediates endocytosis of IgM-coated microbes. Nat Immunol (2000) 1:441-6. doi:10.1038/80886

39. Kikuno K, Kang DW, Tahara K, Torii I, Kubagawa HM, Ho KJ, et al. Unusual biochemical features and follicular dendritic cell expression of human Fcalpha/ mu receptor. Eur J Immunol (2007) 37:3540-50. doi:10.1002/eji.200737655

40. Yoo EM, Trinh KR, Lim H, Wims LA, Morrison SL. Characterization of IgA and IgM binding and internalization by surface-expressed human Fcalpha/mu receptor. Mol Immunol (2011) 48:1818-26. doi:10.1016/j.molimm.2011.05.011

41. Johansen FE, Braathen R, Brandtzaeg P. The J chain is essential for polymeric Ig receptor-mediated epithelial transport of IgA. J Immunol (2001) 167:5185-92. doi:10.4049/jimmunol.167.9.5185

42. Mostov KE, Kraehenbuhl JP, Blobel G. Receptor-mediated transcellular transport of immunoglobulin: synthesis of secretory component as multiple and larger transmembrane forms. Proc Natl Acad Sci U S A (1980) 77:7257-61. doi:10.1073/pnas.77.12.7257

43. Engels N, Konig LM, Heemann C, Lutz J, Tsubata T, Griep S, et al. Recruitment of the cytoplasmic adaptor Grb2 to surface IgG and IgE provides antigen receptor-intrinsic costimulation to class-switched B cells. Nat Immunol (2009) 10:1018-25. doi:10.1038/ni.1764

44. Engels N, Wienands J. The signaling tool box for tyrosine-based costimulation of lymphocytes. Curr Opin Immunol (2011) 23:324-9. doi:10.1016/j. coi.2011.01.005

45. Murakami Y, Narayanan S, Su S, Childs R, Krzewski K, Borrego F, et al. Toso, a functional IgM receptor, is regulated by IL-2 in T and NK cells. J Immunol (2012) 189:587-97. doi:10.4049/jimmunol.1200840

46. Rolink AG, Winkler T, Melchers F, Andersson J. Precursor B cell receptordependent $\mathrm{B}$ cell proliferation and differentiation does not require the bone marrow or fetal liver environment. J Exp Med (2000) 191:23-32. doi:10.1084/ jem.191.1.23

47. Johnson K, Hashimshony T, Sawai CM, Pongubala JM, Skok JA, Aifantis I, et al. Regulation of immunoglobulin light-chain recombination by the transcription factor IRF-4 and the attenuation of interleukin-7 signaling. Immunity (2008) 28:335-45. doi:10.1016/j.immuni.2007.12.019

48. Nguyen TT, Elsner RA, Baumgarth N. Natural IgM prevents autoimmunity by enforcing B cell central tolerance induction. J Immunol (2015) 194:1489-502. doi:10.4049/jimmunol.1401880
49. Baker N, Ehrenstein MR. Cutting edge: selection of B lymphocyte subsets is regulated by natural IgM. J Immunol (2002) 169:6686-90. doi:10.4049/ jimmunol.169.12.6686

50. Boes M, Esau C, Fischer MB, Schmidt T, Carroll M, Chen J. Enhanced B-1 cell development, but impaired IgG antibody responses in mice deficient in secreted IgM. J Immunol (1998) 160:4776-87.

51. Honjo K, Kubagawa Y, Suzuki Y, Takagi M, Ohno H, Bucy RP, et al. Enhanced auto-antibody production and Mott cell formation in FcmuR-deficient autoimmune mice. Int Immunol (2014) 26:659-72. doi:10.1093/intimm/dxu070

52. Boes M, Schmidt T, Linkemann K, Beaudette BC, Marshak-Rothstein A, Chen J. Accelerated development of IgG autoantibodies and autoimmune disease in the absence of secreted IgM. Proc Natl Acad Sci U S A (2000) 97:1184-9. doi:10.1073/pnas.97.3.1184

53. Ehrenstein MR, Cook HT, Neuberger MS. Deficiency in serum immunoglobulin (Ig)M predisposes to development of IgG autoantibodies. J Exp Med (2000) 191:1253-8. doi:10.1084/jem.191.7.1253

54. Brenner D, Brustle A, Lin GH, Lang PA, Duncan GS, Knobbe-Thomsen CB, et al. Toso controls encephalitogenic immune responses by dendritic cells and regulatory T cells. Proc Natl Acad Sci U S A (2014) 111:1060-5. doi:10.1073/ pnas.1323166111

55. Gaublomme JT, Yosef N, Lee Y, Gertner RS, Yang LV, Wu C, et al. Single-cell genomics unveils critical regulators of Th17 cell pathogenicity. Cell (2015) 163:1400-12. doi:10.1016/j.cell.2015.11.009

56. Yang XO, Chang SH, Park H, Nurieva R, Shah B, Acero L, et al. Regulation of inflammatory responses by IL-17F. J Exp Med (2008) 205:1063-75. doi:10.1084/jem.20071978

57. Lang PA, Meryk A, Pandyra AA, Brenner D, Brustle A, Xu HC, et al. Toso regulates differentiation and activation of inflammatory dendritic cells during persistence-prone virus infection. Cell Death Differ (2015) 22:164-73. doi:10.1038/cdd.2014.138

58. Atkinson C, Qiao F, Yang X, Zhu P, Reaves N, Kulik L, et al. Targeting pathogenic postischemic self-recognition by natural IgM to protect against posttransplantation cardiac reperfusion injury. Circulation (2015) 131:1171-80. doi:10.1161/CIRCULATIONAHA.114.010482

59. Haas MS, Alicot EM, Schuerpf F, Chiu I, Li J, Moore FD, et al. Blockade of self-reactive IgM significantly reduces injury in a murine model of acute myocardial infarction. Cardiovasc Res (2010) 87:618-27. doi:10.1093/cvr/cvq141

60. Kulik L, Fleming SD, Moratz C, Reuter JW, Novikov A, Chen K, et al. Pathogenic natural antibodies recognizing annexin IV are required to develop intestinal ischemia-reperfusion injury. J Immunol (2009) 182:5363-73. doi:10.4049/ jimmunol.0803980

61. Weiser MR, Williams JP, Moore FD Jr, Kobzik L, Ma M, Hechtman HB, et al. Reperfusion injury of ischemic skeletal muscle is mediated by natural antibody and complement. J Exp Med (1996) 183:2343-8. doi:10.1084/jem.183.5.2343

62. Panzer SE, Laskowski J, Renner B, Kulik L, Ljubanovic D, Huber KM, et al. IgM exacerbates glomerular disease progression in complement-induced glomerulopathy. Kidney Int (2015) 88:528-37. doi:10.1038/ki.2015.120

63. Kaveri SV, Silverman GJ, Bayry J. Natural IgM in immune equilibrium and harnessing their therapeutic potential. J Immunol (2012) 188:939-45. doi:10.4049/jimmunol.1102107

64. Lapke N, Tartz S, Lee KH, Jacobs T. The application of anti-Toso antibody enhances CD8(+) $\mathrm{T}$ cell responses in experimental malaria vaccination and disease. Vaccine (2015) 33:6763-70. doi:10.1016/j.vaccine.2015.10.065

Conflict of Interest Statement: The authors declare that the research was conducted in the absence of any commercial or financial relationships that could be construed as a potential conflict of interest.

Copyright () 2016 Wang, Coligan and Morse. This is an open-access article distributed under the terms of the Creative Commons Attribution License (CC BY). The use, distribution or reproduction in other forums is permitted, provided the original author(s) or licensor are credited and that the original publication in this journal is cited, in accordance with accepted academic practice. No use, distribution or reproduction is permitted which does not comply with these terms. 